\title{
Appraising Agroecological Urbanism: A Vision for the Future of Sustainable Cities
}

\author{
Acga Cheng $1, *\left(\mathbb{D}\right.$, Nurul Syafiqah Noor Azmi ${ }^{1,2} \oplus$, Yin Mei $\mathrm{Ng}^{2}$, Didier Lesueur ${ }^{3,4,5,6}$ and Sumiani Yusoff ${ }^{7}$
}

Citation: Cheng, A.; Noor Azmi, N.S.; Ng, Y.M.; Lesueur, D.; Yusoff, S. Appraising Agroecological Urbanism: A Vision for the Future of Sustainable Cities. Sustainability 2022, 14, 590. https://doi.org/10.3390/su14020590 Academic Editor: Domenico Ronga

Received: 28 November 2021 Accepted: 30 December 2021 Published: 6 January 2022

Publisher's Note: MDPI stays neutral with regard to jurisdictional claims in published maps and institutional affiliations.

Copyright: (C) 2022 by the authors. Licensee MDPI, Basel, Switzerland. This article is an open access article distributed under the terms and conditions of the Creative Commons Attribution (CC BY) license (https:// creativecommons.org/licenses/by/ $4.0 /)$.
1 Functional Omics and Bioprocess Development Laboratoty, Institute of Biological Sciences, Faculty of Science, Universiti Malaya, Kuala Lumpur 50603, Malaysia; syafiqah.noorazmi@um.edu.my

2 Department of Applied Statistics, Faculty of Economics and Administration, Universiti Malaya, Kuala Lumpur 50603, Malaysia; yinmei.ng@um.edu.my

3 School of Life and Environmental Sciences, Faculty of Science, Engineering and Built Environment-Deakin University, Melbourne, VIC 3125, Australia; d.lesueur@deakin.edu.au

4 Centre de Coopération Internationale en Recherche Agronomique pour le Développent (CIRAD), UMR Eco\&Sols, Hanoi 10000, Vietnam

5 Eco\&Sols, University of Montpellier (UMR), Centre de Coopération Internationale en Recherche Agronomique pour le Développent (CIRAD), Institut National de la Recherche Agronomique (INRAE), Institut de Recherche pour le Développent (IRD), Montpellier SupAgro, 34060 Montpellier, France

6 Alliance of Bioversity International and International Center for Tropical Agriculture (CIAT), Asia Hub, Common Microbial Biotechnology Platform (CMBP), Hanoi 10000, Vietnam

7 Institute of Earth Sciences, Universiti Malaya, Kuala Lumpur 50603, Malaysia; sumiani@um.edu.my

* Correspondence: acgacheng@um.edu.my; Tel.: +60-3-79674351

\begin{abstract}
By the mid-century, urban areas are expected to house two-thirds of the world's population of approximately 10 billion people. The key challenge will be to provide food for all with fewer farmers in rural areas and limited options for expanding cultivated fields in urban areas, with sustainable soil management being a fundamental criterion for achieving sustainability goals. Understanding how nature works in a fast changing world and fostering nature-based agriculture (such as lowinput farming) are crucial for sustaining food systems in the face of worsening urban heat island (UHI) effects and other climatic variables. The best fit for the context is transformative agroecology, which connects ecological networks, sustainable farming approaches, and social movements through change-oriented research and action. Even though agroecology has been practiced for over a century, its potential to address the socioeconomic impact of the food system remained largely unexplored until recently. Agroecological approaches, which involve effective interactions between researchers, policy makers, farmers, and consumers, can improve social cohesion and socioeconomic synergies while reducing the use of various agricultural inputs. This review presents a timeline of agroecology transformation from the past to the present and discusses the possibilities, prospects, and challenges of agroecological urbanism toward a resilient urban future.
\end{abstract}

Keywords: sustainable agriculture; climate change; urban food systems; resilient cities; soil and plant health

\section{Introduction}

The recent coronavirus (COVID-19) pandemic paints a bleak picture of how vulnerable cities are to unforeseen complex global risks and crises. Urban settlements have existed for millennia, since the ancient river valley civilizations of Egypt, China, India, and Mesopotamia. These settlements, which initially depended mainly on domestic agriculture, grew and rose as the centers for merchants and traders [1]. Nonetheless, it was not until the 18th century that cities began to boom, spurred largely by the advent of industrialization [2]. This urban growth, better known as urbanization, has accelerated over the past half-century as large numbers of people have moved to cities for increased employment opportunities and greater access to quality education. Presently, more than 
$50 \%$ of the world's 7.8 billion people live in urban areas [3]. This proportion is projected to rise up to $70 \%$ by mid-century, and the majority of this urbanization is expected to take place in Asia, Latin America, and Africa. Since urbanization is a visible testament to humanity's capacity to modify landscapes and the climate, this continuous growth presents complex challenges for building and sustaining climate-resilient and equitable cities $[4,5]$.

Although cities are the central grounds of economic growth and technological advances, rapid urbanization has been found to result in significant health problems and social inequalities, including poor nutrition, pollution, overcrowding, and poverty [6]. As more cities morphed into sprawling megacities or megapolises, suburbs around the world have grown more briskly, taking up significant tracts of fertile land that was previously utilized for agriculture [7]. The world's urban population is expected to be nearly 6.5 billion in 2050 and ensuring adequate and balanced diets for this population while enhancing food system resilience and urban sustainability will require radical transformations in farming practices, economics, and politics [8].

While urban population growth is concerning, climate change is no less of a threat, emphasizing the need for urban agricultural approaches that can withstand climate change while being sustainable $[5,8]$. The amount of carbon dioxide $\left(\mathrm{CO}_{2}\right)$, the most prevalent greenhouse gas (GHG) that drives climate change, in the atmosphere continues to rise globally, and urban areas account for a whopping three-quarters of $\mathrm{CO}_{2}$ emissions [9]. The main consequence of this is that an urban environment generally experiences much warmer temperatures than its non-urbanized surroundings, a phenomenon known as the urban heat island (UHI) effect. The UHI effect contributes to increased energy consumption and pollution, as well as threats to water quality and human health. While green infrastructure can help to mitigate the UHI effect, the phenomenon is known to interfere with the growth and development of certain plant and animal species, as well as agriculture [9-12].

The agricultural sector is critical to the economies of many countries, particularly those in the developing and least-developed worlds, where urban populations are rapidly increasing. On that account, urban agriculture necessitates a great deal of attention in order to manage urbanization, rapid population growth, food crises, and climate change in a sustainable manner $[7,8]$. Multiple studies have revealed that urban agriculture supports the economic, social, and environmental sustainability of metropolitan areas and have demonstrated how its major or potential trade-offs and synergies compare to those of industrial farming $[8,13]$. Recent events have highlighted the extreme fragility of megacities to unexpected complex global risks and crises-a case in point being the COVID-19 pandemic [14,15]. Climate change is no less of a threat and underscores the need for research on robust urban food systems that are ecologically, economically, and socially sustainable, which can be achieved through transformative agroecology. This article provides an overview of what is known so far about agroecology, particularly in the urban context, addresses the critical knowledge gaps, and furnishes insights into the major opportunities and challenges of adopting agroecological approaches in building sustainable urban food systems in a rapidly changing world.

\section{Then and Now: Agroecology as the Root of Resilience}

Agroecology, which involves farming systems that mimic natural ecosystems, will be a steppingstone toward achieving a suite of Sustainable Development Goals (SDGs), particularly SDG 1 (poverty alleviation), SDG 2 (global food security), and SDG 13 (climate action) [16]. Although the term agroecology was coined in the 1920s, it was not until recently that it began to gain international attention, owing largely to its holistic and nature-based approaches to agriculture. The different branches and varied ideas about the field have led to confusion among researchers and members of the public [16]. Furthermore, the available literature on the adoption of agroecological approaches in urban or metropolitan areas is relatively scarce and fragmented. Encompassing the entire food system, from farm to table to trashcan, agroecology is critical to combating climate change and improving human well-being, thereby safeguarding the planet's future. Some actors (such as researchers 
and policy makers) and funding agencies prefer to talk about Climate Smart Agricultural Practices rather than agroecological practices, but the two are very similar [17].

\subsection{Agroecology Is a Footnote in Agricultural History}

Agroecology, which often involves small-scale farmers with both indigenous (or local) and scientific knowledge, is less well-known in the world than other practices such as conventional or organic farming practices [18,19]. There have been numerous debates about modern agriculture, which includes two distinct philosophies, industrial and agrarian. The comparison of conventional farming and organic farming, which correspond to industrial and agrarian philosophies, is one of the most exemplary representations of the industrial-agrarian dichotomy [20]. The industrial philosophy emphasizes high and efficient production at the lowest possible cost, and it is heavily reliant on external inputs (such as chemical fertilizers) and simplified monocultures, which are typically involved in large-scale farming [21]. On the other hand, the agrarian philosophy recognizes biological diversity and land stewardship as having both environmental and social value, underscoring small-scale farming that emphasizes the sustainable use of ecosystem services and pest and disease management $[16,21]$. Within the agrarian paradigm, there are numerous alternative agriculture movements, including agroecology, which can be viewed as a social movement [20]. Figure 1 illustrates the timeline of agroecology transformation since its inception in the 1920s, as well as major initiatives on building low-carbon, resilient cities since the 1980s.

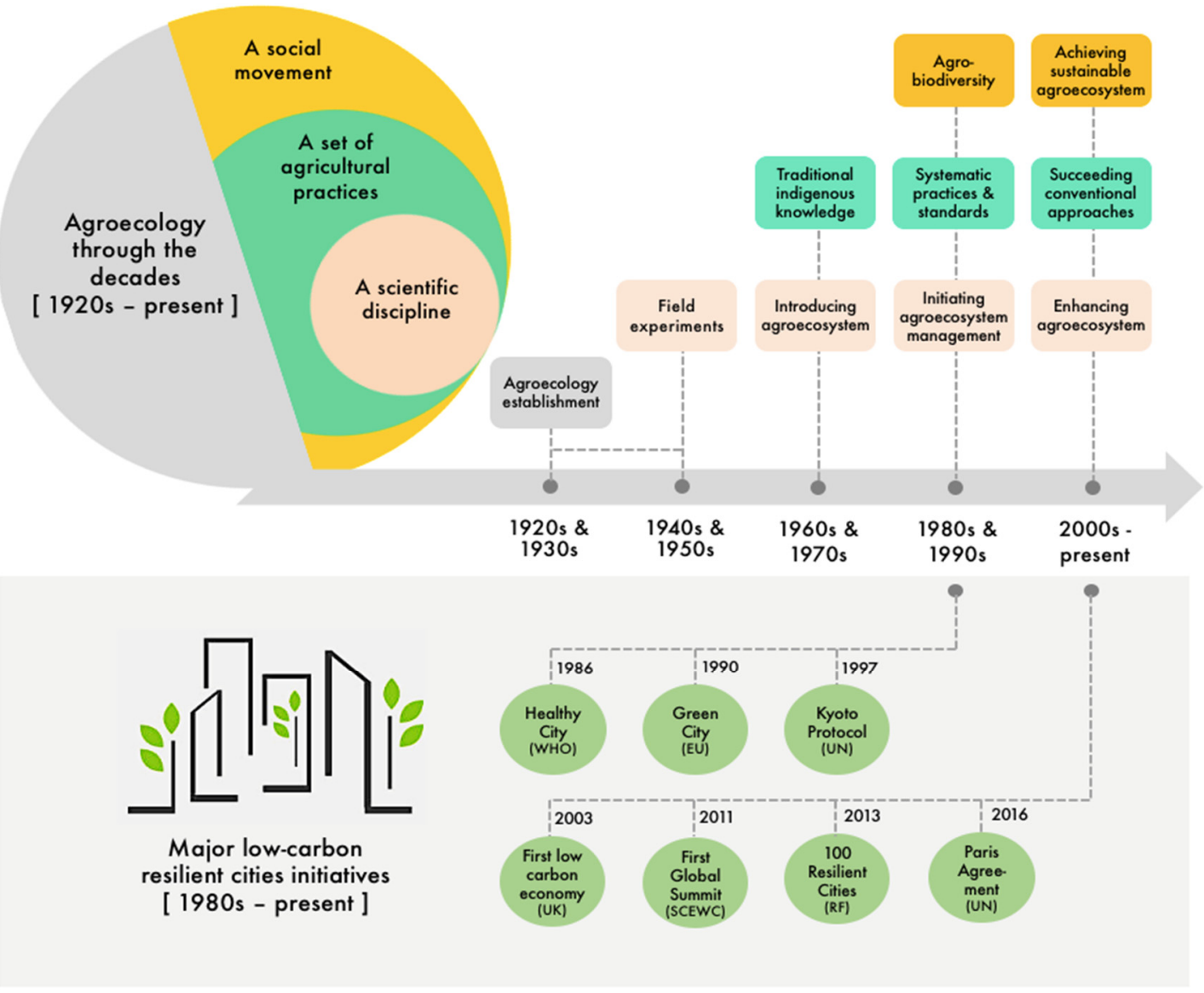

Figure 1. Timeline of agroecology transformation from a scientific discipline to a "science for and with society" approach since the 1920s, and the major initiatives on building low-carbon, resilient cities since the 1980s.

Owing to its fundamental principle that farming should enhance natural systems while maximizing species' diversity, agroecology has evolved from a scientific discipline 
to a set of practices and a social movement that strive for sustainable and resilient food systems (Figure 1). Transformative agroecology, which integrates ecological and social knowledge at multiple scales, can be applied to agricultural systems ranging from agrarian to industrial [20]. Input reduction, higher biodiversity, economic diversification, fairness, co-creation of knowledge, and social values and diets are among the 13 agroecological principles. Furthermore, it employs social-ecological transitions guided by a framework comprised of 10 elements [16,22,23]. In recent years, the International standards requested a low threshold of chemical residues in agricultural products. This contributed to a growing recognition of the importance and positive impacts of agroecological practices on food systems and climate change mitigation, particularly among researchers working toward sustainable agroecosystems [16].

\subsection{The Rise of Urban Agroecology}

The Neolithic and Urban Revolutions are the two major stages in the transformation of hunter-gatherer (or forager) societies. Initial Neolithic domestications are regarded as unconscious evolutionary transformations that began with the cultivation of wild progenitors of domesticated cereals and pulses, which underwent various morphological changes over several millennia [24,25]. As the Neolithic period progressed, settlements became more permanent, and early cities with tens of thousands of inhabitants arose [1]. Gordon Childe coined the term "Urban Revolution" in the 1930s to describe the process by which small, illiterate agricultural villages were transformed into large, socially complex urban societies equipped with indigenous knowledge in traditional farming systems [26,27]. Prior to the Industrial Revolution, these conscious evolutionary transformations occurred independently in several parts of the world, ushering in the era of metropolitan or megalopolitan growth and exurbs' development [28].

Although urbanization provides many social and economic opportunities, it is regarded as one of the most pressing global challenges of the 21st century, with more than $60 \%$ of the world's population expected to live in cities by 2030 , including approximately $55 \%$ and $20 \%$ of the world's poor and undernourished, respectively [29]. Furthermore, the effects of UHI have been reported to pose a significant threat to the world's growing urban societies, affecting energy consumption and increasing emissions of GHGs and air pollutants [30,31]. According to Zhu et al. [32], urban areas consume roughly two-thirds of the world's energy and emit approximately $80 \%$ of GHGs, particularly $\mathrm{CO}_{2}$. On the plus side, over the last three decades, there has been an increase in global initiatives to build low-carbon, resilient cities, with some major examples shown in Figure 1. Promoting and practicing sustainable urban agriculture is currently one of the dominant strategies for addressing urban food insecurity and contributing to climate change mitigation by reducing UHI $[29,33]$. Adoption of agroecology can help to enhance the potential of urban agriculture by emphasizing the importance of building diverse and resilient farms [29].

With a suite of holistic approaches, agroecology can help reorient agricultural systems based on localness, participation, and fairness [16,34]. Table 1 presents some examples of agroecological approaches and their importance in terms of environmental, economic, and social sustainability in cities. Such efforts are consistent with SDG 11, which calls for cities to be inclusive, safe, resilient, and sustainable. Diversification of urban farms is the primary strategy for achieving a sustainable agricultural system in both the biophysical and social spheres [35]. According to Alterie and Nicholls [29], self-sufficiency in vegetables can be achieved at the community or city level if urban farms are redesigned based on an agroecological management. The study also reported that well-designed urban farms can potentially produce up to 15 times the total output of rural holdings. Meanwhile, Kerr et al. [36] reported that 78\% of agroecology studies yielded positive food and nutrition security outcomes. All of these recent studies supported the notion that these agroecological practices must be widely scaled up to ensure widespread adoption by urban farmers. 
Table 1. Examples of components, approaches, and significance of urban agroecology.

\begin{tabular}{|c|c|c|}
\hline Components & Approaches & Significance \\
\hline \multirow{2}{*}{$\begin{array}{l}\text { Agricultural } \\
\text { improvement }\end{array}$} & $\begin{array}{l}\text { Common agroecological practices } \\
\text { (e.g., crop/livestock mixtures) }\end{array}$ & $\begin{array}{l}\text { Preserving soil biodiversity and crop yield sustainability, } \\
\text { crop and animal health, water quality }\end{array}$ \\
\hline & $\begin{array}{l}\text { Urban farm diversification } \\
\text { (e.g., polycultures) }\end{array}$ & More sustainable urban food systems, food sovereignty \\
\hline \multirow{4}{*}{$\begin{array}{l}\text { Ecosystem } \\
\text { services }\end{array}$} & Climate change adaptation & More resilient urban agroecosystems and greenhouse gas regulation \\
\hline & Nutrient cycling & Significant carbon and biological nitrogen fixation potentials \\
\hline & Resource-use efficiency & Improving water management and soil fertility and health \\
\hline & Pest regulation & $\begin{array}{l}\text { Improving pest management through Integrated Pest } \\
\text { Management policies }\end{array}$ \\
\hline \multirow{3}{*}{$\begin{array}{l}\text { Economic or } \\
\text { social value }\end{array}$} & Economic growth & $\begin{array}{l}\text { Equitable distribution of urban-produced foods, economic } \\
\text { self-sustainability }\end{array}$ \\
\hline & Education and awareness & $\begin{array}{l}\text { Economic self-sustainability, management sustainability } \\
\text { (particularly for small-scale farmers/producers) }\end{array}$ \\
\hline & Health & Food quality, noise reduction, stress reduction \\
\hline
\end{tabular}

\section{3. "En Route" to Achieving Resilient Cities through Agroecological Practices}

Extreme heat events caused by climate change, combined with increasing urbanization, will have a direct impact on urban agriculture and food systems [37,38]. Economic slowdowns have been observed in the pandemic's initial epicenters, including China, Europe, and the United States, which have spread to middle- and low-income countries for a variety of reasons, including declines in trade and commodity prices [39]. Under these conditions, it justifies why urban agriculture has emerged as a critical means of addressing local food and nutrition insecurity, particularly through agroecological approaches that benefit smallholder farming systems located in cities, megacities, or megapolises [35,40].

As the late Dr. Norman Borlaug, the father of the Green Revolution, stated, "A peaceful world cannot be built on empty stomachs and human misery". Building resilient food systems through sustainable agriculture is one of the most effective ways to ensure food security, alleviate poverty, accelerate economic growth, and strengthen the middle classes, which are typically the main contributors to economic activity $[36,41]$. To reduce or totally eradicate poverty and hunger locally, regionally, or internationally, it requires better agricultural practices, technologies, policies, and coordination among different actors [16,42]. Figure 2 depicts the lifecycle of innovation through agroecology that should be established to meet the challenges of sustainable development in urban agriculture to pave the way for scientific information to provide significant benefits to society. All actors, including researchers, policy makers, farmers, and citizens, should be able to communicate in scientific terms, and researchers must ensure that their findings are relevant and understandable to society [16]. By building on and strengthening existing networks and interaction among researchers and urban farmers and/or dwellers, agroecology can foster social cohesion and socioeconomic synergies in the exchange of agricultural information and inputs among other benefits $[34,43]$. 


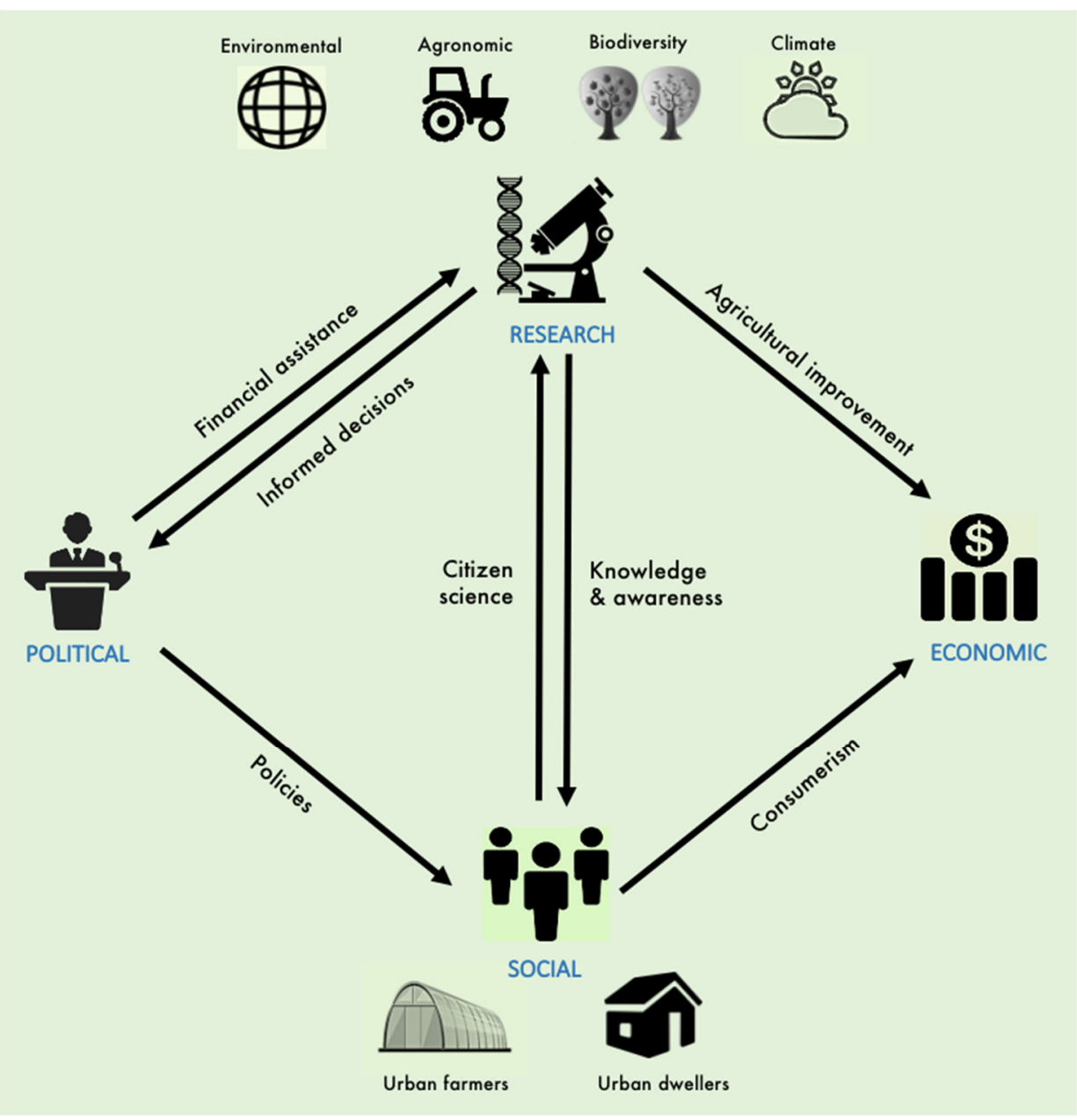

Figure 2. Towards sustainable urban food systems through agroecology, which includes fostering relationships among various key actors such as researchers, policymakers, farmers, and consumers, as well as reducing the use of various agricultural inputs to improve socioeconomic synergies and agricultural sustainability in a rapidly changing world.

For nearly a century, scientific advances have fueled global agricultural growth, allowing producers or farmers from various countries to deliver abundant food domestically. Agricultural diversification has increased dramatically over the last decade, which is known to improve ecosystem service delivery $[35,41,44]$. Among multiple components of diversity that can affect ecosystem service delivery, plant or crop genetic diversity has emerged as the primary determinant of various ecosystem goods and services, including carbon sequestration, pollination, and soil nutrient retention [45]. Nonetheless, a citizen science survey conducted in France by Kondratyeva et al. [46] revealed that urban areas are complex ecosystems that function differently than natural ecosystems due to the human element, with plant communities composed of both locally and regionally unique urbanophile species. The study also demonstrated that citizen science programs are a good starting point for different actors, including researchers, policy makers, and citizens, to exchange knowledge and ideas for sustainable city development.

\section{Is Achieving Sustainability through Urban Agroecology a Catch-22?}

Humans' fundamental need for food poses one of the greatest threats to the planet, as agriculture emits more GHGs than all modes of transportation combined and consumes approximately $70 \%$ of freshwater globally [47]. In the urban context, the triple whammy of population growth, healthier diets, and extreme heat events will necessitate a radical shift in agriculture to ensure that there is enough food for everyone. For example, urban dwellers 
nowadays prefer a more diverse food basket by incorporating some minor grains (such as quinoa and millets) into their diet, resulting in lower consumption of some major cereals (such as maize and rice) [16,48]. This begs the question of how the urban world can double food availability based on varying demand while minimizing the environmental impact of agriculture. In recent years, the long-running debate over the best approach to addressing global food challenges has become more polarized, particularly when conventional and sustainable agriculture are factored in $[49,50]$. Perhaps the most realistic approach is a combination of the best of both as it sounds unrealistic to totally stop using chemical inputs and take them over with organic fertilizers or pesticides. Transformative socialecological approaches are required to sustain the rapid growth of urban populations on all continents except Antarctica (Figure 3).

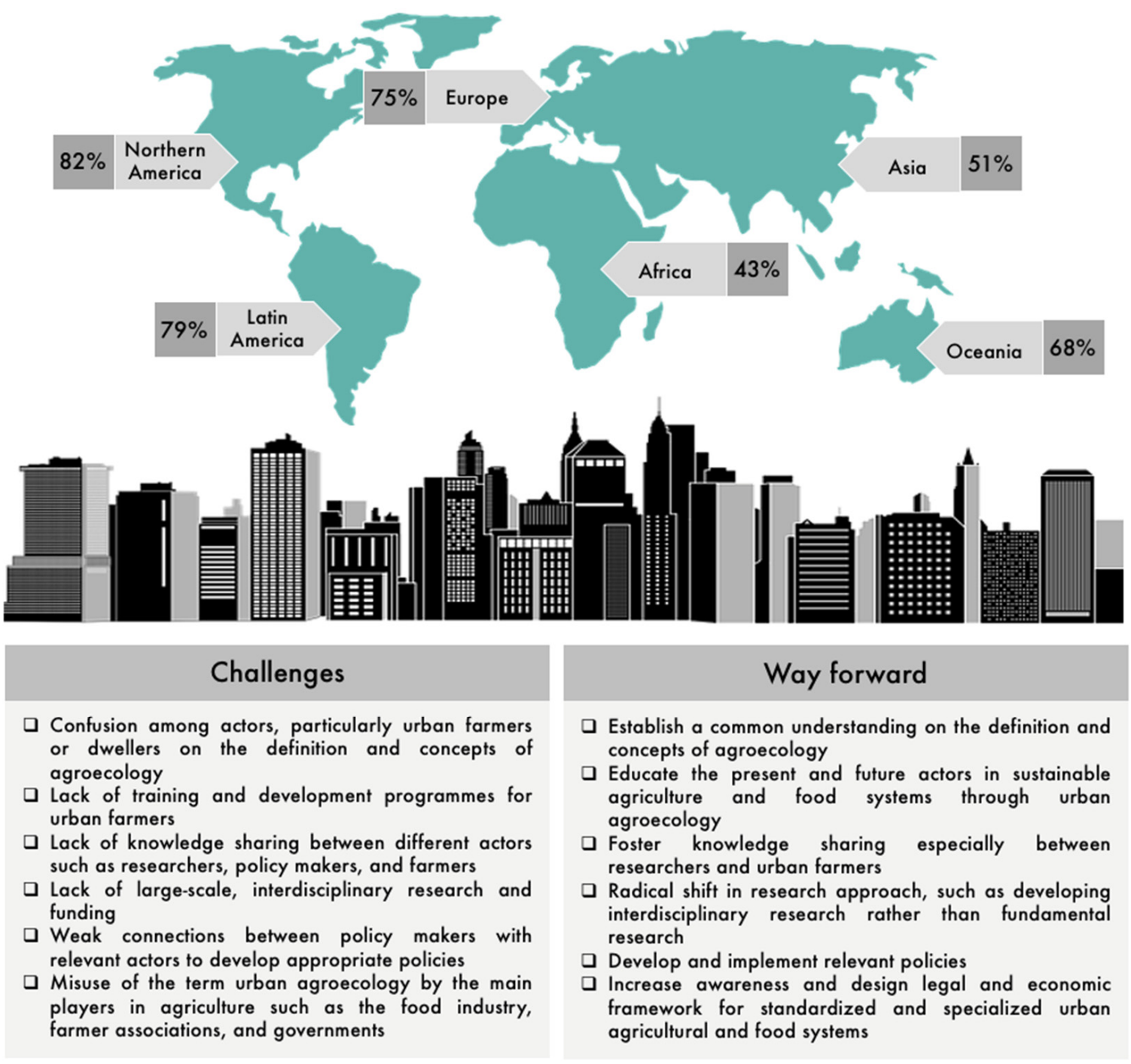

Figure 3. The underlying challenges and considerations of implementing urban agroecology.

Unlike rural agriculture, which often has vast open land to produce labor-intensive crops, urban agriculture typically takes place in limited or confined spaces with a high potential for soil contamination [51,52]. Both urban and peri-urban agriculture is known to be prone to various soil contaminants, such as pesticides, lead, mercury, arsenic, and petroleum products that may be harmful to human health $[52,53]$. On the flip side, due to the abundance of knowledge-based or ecologically skilled farmers and society at large, transforming sustainability in urban agriculture with agroecological approaches is more easily accomplished [54,55]. The enormous potential of urban agroecology (Table 1) should be recog- 
nized and communicated to farmers, policy makers, and communities [56]. It is essential to establish and strengthen specific knowledge and participatory systems among these actors to support urban agroecology, which can ultimately reduce food system vulnerability, primarily through a more diverse system that requires minimal inputs. A global effort by various parties is required to realize the full potential of agricultural diversification through agroecology [41].

While urban agroecology is gaining momentum in many countries, widespread adoption will require appropriate support from various actors (such as decision makers) and public policies $[16,23]$. Furthermore, urban agroecology has its own set of challenges, and appropriate actions must be taken to realize its full potential (Figure 3). Because transformative agroecology is complex and involves multiple aspects, primarily ecology, economics, and social, the main challenge is to establish a dynamic, integrated network capable of bridging the knowledge gap between different actors, particularly between researchers who design climate-resilient urban systems and farmers who will use and manage the systems. A lack of knowledge, limited number of trainings, and/or lack of development programs may explain why farmers do not seriously consider new agricultural approaches such as agroecology as sustainable for them [16]. It is also critical for researchers to highlight novel approaches and address relevant issues to policy makers to develop appropriate policies improving the ecological and socioeconomic resilience of food production.

\section{Conclusions}

In a century marked by rapid climate and social-ecological change, urban food systems around the world face enormous challenges. The recent coronavirus outbreak is a stark reminder that food and health are two of humanity's most basic needs. Through transformative agroecology, sustainable agriculture can improve urban food and nutrition security while preserving ecosystem services. While there are numerous advantages to urban agroecology, it also comes with a set of challenges that necessitate collaborative efforts from all relevant actors. Although there is no "one-size-fits-all" solution to improving urban food and nutrition security, agroecology that supplements natural processes may be the best way forward.

Author Contributions: Writing —original draft preparation, A.C. and N.S.N.A.; writing-review and editing, A.C., N.S.N.A., Y.M.N., D.L. and S.Y.; visualization, N.S.N.A.; supervision, A.C. and Y.M.N.; project administration, A.C.; funding acquisition, A.C. All authors have read and agreed to the published version of the manuscript.

Funding: The Article Processing Charges (APC) were funded by Universiti Malaya, grant number IIRG0002D-2020FNW.

Institutional Review Board Statement: Not applicable.

Informed Consent Statement: Not applicable.

Data Availability Statement: Not applicable.

Acknowledgments: This manuscript was supported by Universiti Malaya. The funder had no role in the preparation of the manuscript.

Conflicts of Interest: The authors declare no conflict of interest. The funders had no role in the design of the study; in the collection, analyses, or interpretation of data; in the writing of the manuscript; or in the decision to publish the results.

\section{References}

1. Fuller, D.Q.; Stevens, C.J. Between domestication and civilization: The role of agriculture and arboriculture in the emergence of the first urban societies. Veget. Hist. Archaeobot. 2019, 28, 263-282. [CrossRef]

2. Fernihough, A.; O'Rourke, K.H. Coal and the European industrial revolution. Econ. J. 2021, 131, 1135-1149. [CrossRef]

3. Ritchie, H.; Roser, M. Urbanization-Our World in Data. 2018. Available online: https:// ourworldindata.org/urbanization (accessed on 10 October 2021). 
4. Chai, D.; Fraedrich, K.; Guan, Y.; Gua, S.; Zhang, C.; Zhu, X. Urbanization and climate change: Insights from eco-hydrological diagnostics. Sci. Total Environ. 2019, 647, 29-36. [CrossRef]

5. World Cities Report. 2020. Available online: https://unhabitat.org/World\%20Cities\%20Report\%202020 (accessed on 1 October 2021).

6. Kuddus, M.A.; Tynan, E.; McBryde, E. Urbanization: A problem for the rich and the poor? Public Health Rev. 2020, 41, 1. [CrossRef] [PubMed]

7. d'Amour, C.B.; Reitsma, F.; Baiocchi, G.; Barthel, S.; Güneralp, B.; Erb, K.H.; Haberl, H.; Creutzig, F.; Seto, K.C. Future urban land expansion and implications for global croplands. Proc. Natl. Acad. Sci. USA 2017, 114, 8939-8944. [CrossRef] [PubMed]

8. Nicholls, E.; Ely, A.; Birkin, L.; Basu, P.; Goulson, D. The contribution of small-scale food production in urban areas to the sustainable development goals: A review and case study. Sustain. Sci. 2020, 15, 1585-1599. [CrossRef]

9. Churkina, G. The Role of Urbanization in the Global Carbon Cycle. Front. Ecol. Evol. 2016, 3, 144. [CrossRef]

10. Dubbeling, M.; Veenhuizen, R.; Halliday, J. Urban agriculture as a climate change and disaster risk reduction strategy. Field Actions Sci. Rep. 2019, 20, 32-39.

11. Li, D.; Stucky, B.J.; Deck, J.; Baiser, B.; Guralnick, R.P. The effect of urbanization on plant phenology depends on regional temperature. Nat. Ecol. Evol. 2019, 3, 1661-1667. [CrossRef]

12. Ribeiro, H.V.; Rybski, D.; Kropp, J.P. Effects of changing population or density on urban carbon dioxide emissions. Nat. Commun 2019, 10, 1-9. [CrossRef]

13. Azunre, G.A.; Amponsah, O.; Peprah, C.; Takyi, S.A.; Braimah, I. A review of the role of urban agriculture in the sustainable city discourse. Cities 2019, 93, 104-119. [CrossRef]

14. Langemeyer, J.; Madrid-Lopez, C.; Beltran, A.M.; Mendez, G.V. Urban agriculture-A necessary pathway towards urban resilience and global sustainability? Landsc. Urban Plan. 2021, 210, 104055. [CrossRef]

15. Pulighe, G.; Lupia, F. Food First: COVID-19 outbreak and cities lockdown a booster for a wider vision on urban agriculture. Sustainability 2020, 12, 5012. [CrossRef]

16. Sethuraman, G.; Mohd Zain, N.A.; Yusoff, S.; Ng, Y.M.; Baisakh, N.; Cheng, A. Revamping Ecosystem Services Through Agroecology-The Case of Cereals. Agriculture 2021, 11, 204. [CrossRef]

17. Sahruzaini, N.A.; Rejab, N.A.; Harikrishna, J.A.; Khairul Ikram, N.K.; Ismail, I.; Kugan, H.M.; Cheng, A. Pulse Crop Genetics for a Sustainable Future: Where We Are Now and Where We Should Be Heading. Front. Plant. Sci. 2020, 11, 531. [CrossRef] [PubMed]

18. Seufert, V.; Ramankutty, N.; Foley, J.A. Comparing the yields of organic and conventional agriculture. Nature 2012, 485, 229-232. [CrossRef] [PubMed]

19. Seminar, A.U.; Sarwoprasodjo, S.; Santosa, D.A.; Kinseng, R.A. Agroecological Education Aimed at Achieving Food Sovereignty. J. Dev. Sustain. Agric. 2017, 12, 34-44. [CrossRef]

20. Shennan, C.; Krupnik, T.J.; Baird, G.; Cohen, H.; Forbush, K.; Lovell, R.J.; Olimpi, E.M. Organic and Conventional Agriculture: A useful framing? Annu. Rev. Environ. Resour. 2017, 42, 317-346. [CrossRef]

21. National Research Council (NRC). Advancing the Science of Climate Change; The National Academies Press: Washington, DC, USA, 2010. [CrossRef]

22. Barrios, E.; Gemmill-Herren, B.; Bicksler, A.; Siliprandi, E.; Brathwaite, R.; Moller, S.; Batello, C.; Tittonell, P. The 10 Elements of Agroecology: Enabling transitions towards sustainable agriculture and food systems through visual narratives. Ecosyst. People 2020, 16, 230-247. [CrossRef]

23. Wezel, A.; Goris, M.; Bruil, J.; Félix, G.; Peeters, A.; Bàrberi, P.; Bellon, S.; Migliorini, P. Challenges and Action Points to Amplify Agroecology in Europe. Sustainability 2018, 10, 1598. [CrossRef]

24. Fuller, D.Q.; Denham, T.; Arroyo-Kalin, M.; Lucas, L.; Stevens, C.J.; Qin, L.; Allaby, R.G.; Purugganan, M.D. Convergent evolution and parallelism in plant domestication revealed by an expanding archaeological record. Proc. Natl. Acad. Sci. USA 2014, 111, 6147-6152. [CrossRef]

25. Allaby, R.G.; Stevens, C.J.; Lucas, L.; Maeda, O.; Fuller, D.Q. Geographic mosaics and changing rates of cereal domestication. Philos. Trans. R. Soc. B 2017, 372, 1735. [CrossRef] [PubMed]

26. Childe, V.G. Man Makes Himself; Watts \& Co: London, UK, 1936.

27. Childe, V.G. The urban revolution. Town Plan. Rev. 1950, 21, 3-17. Available online: http://www.jstor.org/stable/40102108 (accessed on 11 November 2021). [CrossRef]

28. Gotham, K.F. Urban Revolution. In The Blackwell Encyclopedia of Sociology; Ritzer, G., Ed.; John Wiley \& Sons, Inc.: Hoboken, NJ, USA, 2015. [CrossRef]

29. Altieri, M.A.; Nicholls, C.I. Agroecology and the reconstruction of a post-COVID-19 agriculture. J. Peasant Stud. 2020, 47, 881-898. [CrossRef]

30. Shen, Z.; Shi, J.; Tan, J.; Yang, H. The Migration of the Warming Center and Urban Heat Island Effect in Shanghai during Urbanization. Front. Earth Sci. 2020, 8, 340. [CrossRef]

31. Filho, W.L.; Wolf, F.; Castro-Díaz, R.; Li, C.; Ojeh, V.N.; Gutiérrez, N.; Nagy, G.J.; Savić, S.; Natenzon, C.E.; Quasem Al-Amin, A.; et al. Addressing the Urban Heat Islands Effect: A Cross-Country Assessment of the Role of Green Infrastructure. Sustainability 2021, 13, 753. [CrossRef]

32. Zhu, Z.; Wang, L.; Liu, W.; Qi, D. Relationship between Urban Economic Connections and Geoeconomic Relations in Northeast China. Complexity 2020, 2020, 1-12. [CrossRef] 
33. Lucertini, G.; DiGiustino, G. Urban and Peri-Urban Agriculture as a Tool for Food Security and Climate Change Mitigation and Adaptation: The Case of Mestre. Sustainability 2021, 13, 5999. [CrossRef]

34. Kansanga, M.M.; Luginaah, I.; Bezner Kerr, R.; Lupafya, E.; Dakishoni, L. Beyond ecological synergies: Examining the impact of participatory agroecology on social capital in smallholder farming communities. Int. J. Sustain. Dev. World Ecol. 2019, $27,1-14$. [CrossRef]

35. Bisoffi, S.; Ahrné, L.; Aschemann-Witzel, J.; Báldi, A.; Cuhls, K.; DeClerck, F.; Duncan, J.; Hansen, H.O.; Hudson, R.L.; Kohl, J.; et al. COVID-19 and Sustainable Food Systems: What Should We Learn Before the Next Emergency. Front. Sustain. Food Syst. 2021, 5, 650987. [CrossRef]

36. Kerr, R.B.; Madsen, S.; Stüber, M.; Liebert, J.; Enloe, S.; Borghino, N.; Parros, P.; Mutyambai, D.M.; Prudhon, M.; Wezel, A. Can agroecology improve food security and nutrition? A review. Glob. Food Secur. 2021, 29, 100540. [CrossRef]

37. Khan, N.; Shahid, S.; Ahmed, K.; Wang, X.; Ali, R.; Ismail, T.; Nawaz, N. Selection of GCMs for the projection of spatial distribution of heat waves in Pakistan. Atmos. Res. 2020, 233, 104688. [CrossRef]

38. Food and COVID-19: How Cities Are Feeding Residents Today and Building a Better Tomorrow. C40 Cities, Climate Leadership Group, C40 Knowledge Hub. 2020. Available online: https: / www.c40knowledgehub.org/s/article/Food-and-COVID-19-Howcities-are-feeding-residents-today-and-building-a-better-tomorrow?language=en_US (accessed on 9 September 2021).

39. APF-News Article: Canada Investment Monitor 2021 Report Highlights Opportunities for Canadian Companies in Post-Pandemic Asia. 2021. Available online: https:/ / www.asiapacific.ca/media/news-releases/55788 (accessed on 10 October 2021).

40. FAO-News Article: International Year of Family Farming 2014 Launched. 2014. Available online: www.fao.org/family-farming2014 (accessed on 13 September 2021).

41. Cheng, A. Review: Shaping a Sustainable Food Future by Rediscovering Long-Forgotten Ancient Grains. Plant. Sci. 2018, 269, 136-142. [CrossRef] [PubMed]

42. Hanafiah, N.M.; Mispan, M.S.; Lim, P.E.; Baisakh, N.; Cheng, A. The 21st Century Agriculture: When Rice Research Draws Attention to Climate Variability and How Weedy Rice and Underutilized Grains Come in Handy. Plants 2020, 9, 365. [CrossRef] [PubMed]

43. Méndez, V.E.; Bacon, C.M.; Cohen, R. Agroecology as a transdisciplinary, participatory and action-oriented approach. Agroecol. Sustain. Food Syst. 2013, 37, 3-18.

44. Massawe, F.; Mayes, S.; Cheng, A. Crop Diversity: An Unexploited Treasure Trove for Food Security. Trends Plant. Sci. 2016, 21, 365-368. [CrossRef]

45. Hou, Z.; Lv, G.; Jiang, L. Functional Diversity Can Predict Ecosystem Functions Better Than Dominant Species: The Case of Desert Plants in the Ebinur Lake Basin. Sustainability 2021, 13, 2858. [CrossRef]

46. Kondratyeva, A.; Knapp, S.; Durka, W.; Kühn, I.; Vallet, J.; Machon, N.; Martin, G.; Motard, E.; Grandcolas, P.; Pavoine, S Urbanization Effects on Biodiversity Revealed by a Two-Scale Analysis of Species Functional Uniqueness vs. Redundancy. Front. Ecol. Evol. 2020, 8, 73. [CrossRef]

47. Ritchie, H.; Roser, M. $\mathrm{CO}_{2}$ and Greenhouse Gas Emissions. 2020. Available online: https://ourworldindata.org/co2-and-othergreenhouse-gas-emissions (accessed on 15 September 2021).

48. Szabo, S. Urbanisation and Food Insecurity Risks: Assessing the Role of Human Development. Oxf. Dev. Stud. 2016, 44, 28-48. [CrossRef]

49. Robinson, G.M. Towards sustainable agriculture: Current debates. Geogr. Compass 2009, 3, 1757-1773. [CrossRef]

50. Siebrecht, N. Sustainable Agriculture and Its Implementation Gap-Overcoming Obstacles to Implementation. Sustainability 2020, 12, 3853. [CrossRef]

51. McDougall, R.N.; Kristiansen, P.; Rader, R. Small-scale urban agriculture results in high yields but requires judicious management of inputs to achieve sustainability. Proc. Natl. Acad. Sci. USA 2019, 116, 129-134. [CrossRef]

52. Paltseva, A.A.; Cheng, Z.; Egendorf, S.P.; Groffman, P.M. Remediation of an urban garden with elevated levels of soil contamination. Sci. Total Environ. 2020, 722, 137965. [CrossRef] [PubMed]

53. Kessler, R. Urban gardening: Managing the risks of contaminated soil. Env. Health Perspect. 2013, 121, A326-A333. [CrossRef] [PubMed]

54. Grebitus, C.; Chenarides, L.; Muenich, R.; Mahalov, A. Consumers' Perception of Urban Farming-An Exploratory Study. Front. Sustain. Food Syst. 2020, 4, 79. [CrossRef]

55. Nicol, P. Pathways to Scaling Agroecology in the City Region: Scaling out, Scaling Up and Scaling Deep through Community-Led Trade. Sustainability 2020, 12, 7842. [CrossRef]

56. Nicklay, J.A.; Cadieux, K.V.; Rogers, M.A.; Jelinski, N.A.; LaBine, K.; Small, G.E. Facilitating Spaces of Urban Agroecology: A Learning Framework for Community-University Partnerships. Front. Sustain. Food Syst. 2020, 4, 143. [CrossRef] 